\title{
Reshaping Agriculture Using the Nuclear Techniques: The Pakistan Case
}

\author{
Mukhtar Ahmed Rana \\ Technical Services Division, Nuclear Institute of Agriculture (NIA), Tandojam, Hyderabad, Sindh, Pakistan \\ Email: ranamssa@gmail.com
}

How to cite this paper: Rana, M.A. (2018) Reshaping Agriculture Using the Nuclear Techniques: The Pakistan Case. Agricultural Sciences, 9, 1168-1172.

https://doi.org/10.4236/as.2018.99081

Received: August 18, 2018

Accepted: September 18, 2018

Published: September 21, 2018

Copyright (C) 2018 by author and Scientific Research Publishing Inc. This work is licensed under the Creative Commons Attribution International License (CC BY 4.0).

http://creativecommons.org/licenses/by/4.0/

\begin{abstract}
The field of nuclear agriculture is introduced very briefly. Nuclear agriculture research/development system in Pakistan is described highlighting the achievements of the system partners. Description and discussion are generalized in concluding remarks at the end of the article. This article is an experimental guide for a developing nuclear agriculture system.
\end{abstract}

\section{Keywords}

Nuclear Agriculture, The PAEC, Crop Varieties, Hunger

\section{Introduction to Nuclear Agriculture}

Agriculture has been the backbone of the development throughout the human history. It helps us in the production of foods, clothing and the raw materials for the old and modern industry, details in the refs. [1]-[6]. Nuclear agriculture refers to the application of nuclear techniques and methods in the field of agriculture. It is an example of peaceful uses of nuclear technology. No residual radiation is left in the plants developed through radiation induced mutations. Generalized objectives in agriculture are high yield, wide adaptability and stability in performance, tolerance to diseases and abiotic stresses, e.g., drought, heat, cold, and salinity etc. Induced mutations are the least hazardous in developing resistance in plants against diseases and insect pests. Important aspects of mutation breeding include desirable plant characters, mutability, genetic manipulation and genetic analysis. Detection of rare genetic variants in large populations is difficult. Selection of genetic variants in mutation breeding is critical. Selection errors occur due to a number of reasons including wrong selection criteria, inadequate techniques, lack of accuracy and too low screening population. Mutations induced by radiation or chemical mutagens include a small fraction of 
useful genetic alterations. Very small fraction of induced mutants $(<1 \%)$ get selected for yield trials and further only $1 \%$ of selected and evaluated mutants qualify official tests and obtain approval of commercial utilization in the form of a variety. Nuclear agriculture is an active area of research and development around the world. Use of nuclear techniques in agriculture is helping to provide food security to third world countries of Asia and Africa (photos in Figure 1).

\section{Nuclear Agriculture Research/Development System in Pakistan}

Nuclear agriculture is among priorities of Pakistan's neighbors India and China. Pakistan is not behind its neighbors in nuclear agriculture and has developed close to 100 new varieties of various crops including wheat, cotton, rice, lentil, chickpea, brassica and sugarcane, etc. Developed varieties have higher yield potential and resistance against diseases and insect pests than their parent varieties. Pakistan Atomic Energy Commission (PAEC) has paid considerable attention to promote the nuclear techniques for the development of agriculture sector in the country. PAEC and its agriculture research system of institutions include Nuclear Institute of Agriculture (NIA), Tandojam, Nuclear Institute for Agriculture and Biology (NIAB), Faisalabad, Nuclear Institute for Food and Agriculture (NIFA), Peshawar and National Institute of Biotechnology and Genetic Engineering (NIBGE), Faisalabad. They have played an important role in the development of new crop varieties by using the nuclear techniques in agriculture. Development of crop varieties is a slow process as it takes 12 - 15 years to develop new varieties and to achieve stability in performance.

Table 1 gives nuclear agriculture development in Pakistan. It shows start-up years of PAEC institutes working on agriculture and related fields. These institutes work in coordination and competition with each other compelling them to keep active in useful research and development ( $R \& D$ ) work. A number of crop varieties have been developed by PAEC institutes (Table 2). Wheat, cotton, rice and sugarcane are major crops on which breeding work through radiation induced mutations is being conducted at PAEC institutes. Varieties of 8 different crops are released which shows the broad scope of breeding work continued at PAEC agriculture centers. PAEC agriculture centres have developed new technologies, crop varieties and instruments/methods related to the agriculture. They have transferred the developed technologies to the end users or farmers. The released crop varieties have resulted in outstanding improvement in productivity and tolerance of the crops.

A number of varieties of above mentioned crops have been released by the PAEC's agriculture institutes. These varieties cover significant fraction of crop areas in the country. NIAB-78, released by NIAB, Faisalabad, is a cotton variety which covered more than $70 \%$ of the area under cotton in Pakistan. Sarsabz (1985) and Kiran (1992), both released by NIA, Tandojam are very successful wheat varieties and covers more than $30 \%$ area under wheat in Sindh. Kiran still 

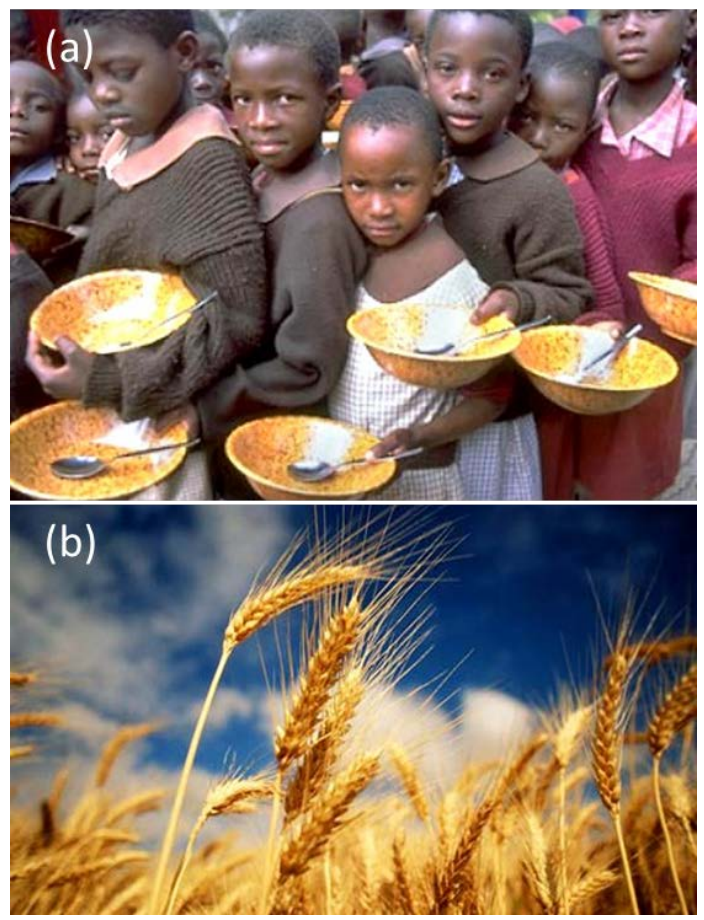

Figure 1. (a) Hunger circumstances [7] and (b) agriculture as the food source [8].

Table 1. PAEC Institutes working on nuclear agriculture and related fields.

\begin{tabular}{cc}
\hline Institute & Starting Year \\
\hline NIA, Tandojam, Sindh & 1963 \\
NIAB, Faisalabad, Punjab & 1972 \\
NIFA, Peshawar, Khyber Pakhtunkhah & 1982 \\
NIBGE, Faisalabad, Punjab & 1994 \\
\hline
\end{tabular}

Table 2. Crop varieties developed by the PAEC institutes.

\begin{tabular}{cccccc}
\hline Crop/Institute & NIA & NIAB & NIFA & NIBGE & Total \\
\hline Brassica & 1 & & 4 & 7 & 5 \\
Cotton & 4 & 12 & & 23 \\
Chickpea & 1 & 2 & & 9 & 3 \\
Lentil & 1 & 11 & 1 & 13 \\
Mungbean & 3 & & & 3 \\
Sugarcane & 6 & 3 & & & 9 \\
Rice & 13 & & 7 & 7 & 85 \\
Wheat & 29 & 33 & 16 & & 20 \\
Total & & & & \\
\hline
\end{tabular}

${ }^{*}$ Consultation for data in this table: Dr. N. Iqbal, PAEC Headquarters, Islamabad; Dr. K.D. Jamali, NIA, Tandojam. Accessible data about the periods of crop varieties are mentioned in the text. 
dominates in Sindh province covering more than $25 \%$ of land under wheat. Shandar is a rice variety, released by NIA dominates and covers more than $50 \%$ of area under rice in Sindh. NIA has released rice variety Shua for saline lands. Saduri is the best cotton variety released by NIA and it covers more than $25 \%$ of land under cotton in Sindh. NIA-2004 is a sugarcane variety, released by NIA, which is very popular in Sindh. Pakistan is an agricultural state where crop improvement can have a significant impact on the national economy. So, agriculture R\&D in Pakistan is very important.

\section{Concluding Remarks}

Rising world population requires the increase of food production and decrease of crop losses. Nuclear techniques in agriculture can help in achieving the goal of matching food production with its demand by developing high yield and stress resistant crop varieties. Pakistan is applying scientific knowledge/experience in solving the problems of agriculture. Pakistan has produced a number of stress-resistant/tolerant crop varieties. Programs relating to insect control and soil management for better crops are active in the country. PAEC is doing nuclear R\&D in 5 thematic programs of agriculture, plant breeding, soil science, plant protection, plant physiology and animal sciences. PAEC's achievements in nuclear agriculture are admirable. Nuclear agriculture institutions in Pakistan have improved agriculture in the country through release of better crop varieties suitable for local conditions. Nuclear agriculture is helping in the fight against the hunger. Other breeding technologies are described in Refs. [9]-[12] and references therein.

\section{Acknowledgements}

Useful discussions with Mr. Muhammad Yousuf Memon (Director NIA), Dr. Nazir Ahmad, Mr. Abdullah Khatri, and Dr. Azeem Asad are gratefully acknowledged and appreciated. Author is basically a physicist who worked in agriculture as a visiting scientist during 2014-15.

\section{Conflicts of Interest}

The author declares no conflicts of interest regarding the publication of this paper.

\section{References}

[1] Johnston, B.F. and Mellor, J.W. (1961) The Role of Agriculture in Economic Development. The American Economic Review, 51, 566-593.

[2] Brown, A. (2016) Agriculture: World without Deforestation. Nature Climate Change, 6, 541. https://doi.org/10.1038/nclimate3047

[3] Shang, X.F., Liu, Y.Q., Guo, X., Miao, X.L., Chen, C., Zhang, J.X. and Zhang, X.S. (2018) Application of Sustainable Natural Resources in Agriculture: Acaricidal and Enzyme Inhibitory Activities of Naphthoquinones and Their Analogs against Pso- 
roptescuniculi. Scientific Reports, 8, 1609.

https://doi.org/10.1038/s41598-018-19964-0

[4] Levy, M.A., Lubell, M.N. and McRoberts, N. (2018) The Structure of Mental Models of Sustainable Agriculture. Nature Sustainability, 1, 413-420.

https://doi.org/10.1038/s41893-018-0116-y

[5] Pretty, J.N. (1995) Participatory Learning for Sustainable Agriculture. World Development, 23, 1247-1263.

De Wrachien, D. and Goli, M. (2015) Global Warming Effects on Irrigation Development and Crop Production: A World-Wide View. Agricultural Sciences, 6, 734-747.

[6] De Wrachien, D. and Goli, M. (2015) Global Warming Effects on Irrigation Development and Crop Production: A World-Wide View. Agricultural Sciences, 6, 734-747. https://doi.org/10.4236/as.2015.67071

[7] Ghana News (2018) Africa Dominating Rising Global Hunger Rates. https://www.myjoyonline.com/ghana-news/

[8] AgriLand Media Limited (2017). https://www.agriland.ie

[9] Schaart, J.G., van de Wiel, C.C., Lotz, L.A. and Smulders, M.J. (2016) Opportunities for Products of New Plant Breeding Techniques. Trends in Plant Science, 21, 438-449. https://doi.org/10.1016/j.tplants.2015.11.006

[10] Kasai, A. and Harada, T. (2015) Epimutant Induction as a New Plant Breeding Technology. Japan Agricultural Research Quarterly: JARQ, 49, 301-305. https://doi.org/10.6090/jarq.49.301

[11] Promnart, U., Puripunyavanich, V., Boonsirichai, K., Doungsoongnern, P., Kaewchuenchai, R., Chamotri, S., Klakhaeng, K. and Sarsu, F. (2017) Breeding Thai Rice for Flood Tolerance through Electron Beam-Induced Mutations. International Journal of Genetic Engineering, 5, 1-10.

[12] Chen, T., Chen, G., Yang, S., Zhao, Y., Ha, Y. and Ye, Z. (2017) Recent Developments in the Application of Nuclear Technology in Agro-Food Quality and Safety Control in China. Food Control, 72, 306-312. https://doi.org/10.1016/j.foodcont.2015.08.034 